\title{
RURAL TOURISM: THE ESSENCE AND ASPECTS OF CONCEPTS AND TERMINOLOGY
}

\author{
'Natalia MATVIYENKO, 2Iryna OKOLOVYCH
}

Taras Shevchenko National University of Kyiv, Ukraine
${ }^{1}$ matvienko_natalia@knu.ua, ${ }^{2}$ ira_okolovych@ukr.net

Abstract: Many scientists work on the research of various aspects of the rural tourism functioning, but despite this, in the scientific field still remains the problem of uncertainty and ambiguous interpretation of the definitions in rural tourism, which is primarily due to the multidimensional nature of this type of activity and the lack of understanding of its essence. Therefore, the objective of this article is to study and generalize the terms and concepts that occur in the conceptual field of rural tourism.

Different approaches are applied to determining the essence of rural tourism not only in Ukraine but also abroad. The most common of them is the definition of rural tourism as one being implemented within rural areas. But, in our opinion, this approach is controversial and cannot claim to be the most objective, as in the practices of different countries there is diversity not only in the types and forms of rural tourism, but also in relation to the territorial size of rural administrative units, their definition by population etc. And the peculiarity of rural tourism is not only in its implementation in the countryside, but also in the specifics of tourist services that are provided.

The article analyzes the definition of the "rural tourism" concept proposed by different authors, specifies the use of the terms "rural tourism" and "rural green tourism" in the scientific field, describes the foreign approaches to the definition of rural tourism. The relationship between the concepts of "rural tourism", "agro-tourism" and "ecotourism", which is often debatable, is also defined.

It can be argued that rural, agro- and ecotourism have different contents and imply different goals of activity. But in the field of science there is a commonplace approach to understand rural tourism as a kind of synthesis of three varieties - eco-tourism (green), agro-tourism (farmer) and rural tourism. At the same time, the concept of "rural tourism" in its contents is much broader than the concept of "agro-tourism", which acts as one of its most common organizational forms, and to a certain level correlates with the notion of "ecological tourism", although they are not identical.

The article proposes a generalization of the essence, specific features and functions of rural tourism, based on modern research in this direction and the assertion that the main service of rural tourism is not just providing tourists with temporary residence in the country farmstead, but provision of a comprehensive service for tourists, as well as taking into account its role as an instrument for ensuring sustainable socio-economic development of rural areas.

Key words: tourism, tourist, term, rural (green) tourism, agro-tourism, ecotourism, rural farmstead.

DOI: https://doi.org/10.17721/2413-7154/2018.80.28-32

UDC: 379.85

Received: December 17, 2017.

Accepted: December 28, 2018.

\section{СІЛЬСЬКИЙ ТУРИЗМ: СУТНІСТЬ ТА АСПЕКТИ ПОНЯТІЙНО-ТЕРМІНОЛОГІЧНОГО АПАРАТУ}

\author{
'Наталія МАТВІєНКО, ${ }^{2}$ Ірина ОКОЛОВИч \\ Київський начіональний університет імені Тараса Шевченка, Україна

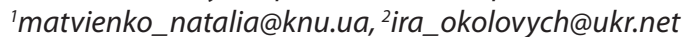

Анотація: Над дослідженням різних аспектів функціонування сільського туризму працюють багато науковців, але, не зважаючи на це, в науковому полі залишається проблема невизначеності і неоднозначного тлумачення дефініцій у сільському туризмі, що пов'язане в першу чергу із багатоаспектністю цього виду діяльності та нерозумінням його сутності. Метою статті $є$ дослідження і узагальнення термінів та понять, що зустрічаються у понятійно-концептуальному полі сільського туризму.

До визначення сутності сільського туризму застосовують різні підходи не тільки в Україні, а й за кордоном. Найпоширенішим з них $\epsilon$ визначення сільського туризму як такого, що здійснюється в межах сільської місцевості. Але, на нашу думку, цей підхід є суперечливим та не може претендувати на максимальну об'єктивність, оскільки в практиках різних країн існують відмінності не тільки щодо видів і форм сільського туризму, а й щодо територіальних розмірів сільських адміністративних одиниць, визначення їх за чисельністю населення тощо. А особливість сільського туризму полягає не лише в проваджені його в сільській місцевості, а й в специфіці туристичних послуг, які надаються.

В статті запропоноване узагальнення сутності, специфічних рис та функцій сільського туризму, базуючись на сучасних дослідженнях з цього напрямку та виходячи із твердження, що основна послуга сільського туризму - це не просто надання туристам тимчасового проживання в сільській садибі, а формування комплексного обслуговування тих, хто відпочиває, а також беручи до уваги його роль як інструменту забезпечення сталого соціально-економічного розвитку сільських територій.

Ключові слова: туризм, турист, термін, сільський (зелений) туризм, агротуризм, екотуризм, сільська садиба. 
Постановка проблеми. Питання сталого розвитку сільської місцевості стало особливо актуальним та важливим напрямом державної політики в Україні після підписання Угоди про асоціацію «Україна - ЄС». Політика розвитку сільських територій в $€ С$ є частиною загальної сільськогосподарської політики, яка дозволяе вирішити цілий ряд соціальних, економічних, екологічних та інфраструктурних проблем регіонів.

В цьому контексті особливу увагу слід звернути на один із способів диверсифікації сільськогосподарської діяльності, що не потребує значних інвестицій для початкового розвитку, а саме сільський туризм. Адже специфіка сільського туризму полягає в тому, що, крім первинної ролі - задоволення актуальних потреб споживачів, він $\epsilon$ інструментом забезпечення сталого соціальноекономічного розвитку сільських територій, зокрема сприяє збереженню та відродженню традиційної культури та місцевих народних звичаїв, формуванню доходу сільського населення, створенню нових робочих місць.

Експерти Всесвітньої туристичної організації також визначають сільський туризм як один із найперспективніших видів туризму в Україні, про що говорилося в межах туристичної панелі 18 Міжнародного економічного форуму у Львові 1-2 листопада 2018 року [6].

В свою чергу, можливість максимально ефективного використання потенціалу сільського туризму для вирішення вищезазначених проблем сільської місцевості тісно пов'язана із розумінням його сутності, розмежуванням його особливостей та характерних ознак. Не визначеність та неоднозначне тлумачення дефініцій у сільському туризмі викликає плутанину у фахівців, які повинні створювати законодавчі акти та готувати майбутніх спеціалістів 3 туризму.

Аналіз останніх досліджень та публікацій. Аналіз вітчизняної наукової літератури свідчить про те, що питання сільського туризму в Україні досліджуються багатьма науковцями. Зокрема, різним аспектам його функціонування присвячені праці Бирковича В. І., Горішевського П., Кудли Н. Є., Рутинського М. Й., Зінька Ю. В, Дубодєлової А. В., Дарчук В. Г., Іванової В. Г. та ін. В цих працях $є$ певні дискусійні моменти сучасної понятійно-термінологічної бази досліджень сільського туризму. Тому систематизація наявних понять i термінів у цій сфері дослідження $\epsilon$ безумовно актуальною.

Мета та завдання дослідження. Метою дослідження є узагальнення термінів та понять, що зустрічаються у понятійно-концептуальному полі дослідження сільського туризму. Для досягнення поставленої мети було поставлено наступні завдання: 1) проаналізувати наявні визначення і сутність поняття «сільський туризм» та суміжні 3 ним терміни та поняття; 2) узагальнити специфічні риси, особливості та функції сільського туризму.

(C) Natalia Matviyenko, Iryna Okolovych
Виклад основного матеріалу. Незважаючи на стрімкий розвиток самого явища та дослідження його різними науковцями, на сьогодні не існуе однозначного підходу до визначення сутності сільського туризму не тільки в Україні, але й в інших країнах Європи. В першу чергу це пов'язано з диференційованими підходами у різних країнах до сільського туризму як виду діяльності в сільській місцевості.

Особливо ця невизначеність спостерігається в Україні, де законодавчо не закріплений на єдиному рівні понятійно-термінологічний апарат сільського туризму.

Деякі автори визначають сільський туризм як такий, що охоплює усі форми туризму, які зустрічаються у сільській місцевості. Проте прив'язка сільського туризму тільки до сільської місцевості не відображає повною мірою сутнісне визначення. Хоча термін «сільський туризм» співвідноситься Європейською комісією 3 відповідним видом туризму для опису і пояснення всієї туристичної діяльності, що здійснюється в селах та сільській місцевості, існують відмінності в європейських міжнаціональних дефініціях не тільки щодо видів і форм сільського туризму, а й щодо територіальних розмірів сільських адміністративних одиниць, визначення їх за чисельністю населення тощо [2].

Таке визначення, безумовно, $\epsilon$ дуже суперечливим ще й тому, що особливість сільського туризму полягає не лише в проваджені його в сільській місцевості, а й в специфіці туристичних послуг, які надаються.

Так, Биркович В. I. пропонує таке визначення цього поняття: сільський зелений туризм - це специфічна форма відпочинку в приватних господарствах сільської місцевості з використанням майна та трудових ресурсів особистого селянського, підсобного або фермерського господарства, природно-рекреаційних особливостей місцевості та культурної, історичної та етнографічної спадщини регіону [1].

Подібної думки і Васильєв В. П., який стверджує, що сільський зелений туризм - це специфічна форма відпочинку в селі з використанням природного, матеріального та культурного потенціалу даної місцевості. При цьому проживання, харчування та обслуговування туристів забезпечуе сільська родина [7].

За В. Ф. Кифяком, сільський туризм - це тимчасове переміщення туристів в сільську місцевість 3 метою відпочинку і ознайомлення 3 ї способом життя, культурою, традиціями [4].

Тим часом відомі дослідники сільського туризму в Україні Горішевський П. В. та Зінько Ю. В. у своїх наукових дослідженнях наголошують, що під цим терміном варто розуміти відпочинок з будь-якою метою, видом та формою організації туристської подорожі у сільській місцевості з розміщенням у будинку сільського господаря [3].

3 точки зору відносин між споживачем послуг сільського туризму та тим, хто їх надає, Фарйон О. О. визначає сільський туризм як вид підприємницької 
діяльності щодо надання послуг відпочинку в сільській місцевості 3 використанням приватної власності мешканців села та природно-культурноісторичних ресурсів місцевості [12].

Дарчук В. Г. уточнює у своєму визначенні сільського туризму, що, крім розміщення туристів у сільській садибі для відпочинку, цей вид туризму передбачає отримання ними відповідних послуг:

- традиційних основних: проживання (екологічне, культурне, історичне розташування), харчування (екологічно чисті продукти, дегустація місцевих та домашніх страв), розваг (участь у фестивалях, ярмарках, організації традиційних свят);

- традиційних додаткових: робота на фермі, городі, в саду, на господарському дворі, сіновалі, рибалка, полювання;

- та специфічних: догляд за домашніми тваринами, катання на конях, човнах, навчання народним ремеслам тощо [4].

Варто також зауважити, що доповнення в деяких випадках визначення «сільський туризм» означенням «зелений» використовується виключно в українській практиці з метою підкреслення його екологічної спрямованості.

I хоча законодавчо в Україні і закріплено сам термін «сільський зелений туризм», юридичний зміст якого трактується як відпочинок в українському селі, але конкретно не визначено його сутності, a в законодавчих i нормативних актах немає понятійної єдності [7].

Так, в деяких нормативних актах, наприклад Законі України «Про особисте селянське господарство» від 15.05.2003 р. чи Законі України «Про сільськогосподарську дорадчу діяльність» від 17.06.2004 р., вживається термін «сільський зелений туризм», а в Законі України «Про податок з доходів фізичних осіб» від 22.05.2003 р. чи Законі України «Про туризм» від 15.09.1995 р. зустрічається поняття «сільський туризм» [7].

Відмінними $є$ також підходи до визначення сільського туризму за кордоном.

Так, литовське туристичне законодавство формулює положення, що сільський туризм - це послуги тимчасового проживання у сільській садибі.

В Угорщині також немає визначення сільського туризму на законодавчому рівні. Традиційно вживаються словосполучення: «сільська хутірська гостинність», «сільський туризм», «сільський аграрний туризм», які окреслюють різновид робіт i послуг, які виконуються чи надаються сільськими мешканцями у процесі господарювання у власних садибах.

У Швеції поширене поняття «сільська гостинність» - коли гості можуть займати частину будинку господаря, мати окремі кімнати, проживати в окремому будинку або у наметах на території господарства, а у Данії зазначена категорія характеризується як обслуговування туристів, які приїхали у село, завдяки чому місцеві жителі отримують додатковий прибуток [7].
Експерти Всесвітньої туристичної організації погоджуються на думці, що сільський туризм складна багатоаспектна діяльність, що включає в себе пішохідні прогулянки, гірські походи, кінні прогулянки, спортивні та оздоровчі подорожі, полювання й рибальство, а також інші, менш спеціалізовані форми туризму [9].

Беручи багатоаспектність сільського туризму до уваги, варто зазначити, що важливе місце у визначенні сутності цього виду туризму займає встановлення співвідношень між поняттями «сільський» та «зелений», «екологічний», «аграрний», «фермерський» туризм, які дуже часто науковцями ототожнюються.

Британський словник 3 подорожей, туризму та гостинності С. Медліка визначає, що сільський туризм (rural tourism) - це відпочинковий вид туризму, сконцентрований на сільських територіях. Він передбачає розвиток туристичних шляхів, місць для відпочинку, сільськогосподарських і народних музеїв, а також центрів 3 обслуговування туристів 3 провідниками та екскурсоводами [9].

Агротуризм (farm tourism) - це відпочинковий туризм, що передбачає використання сільського (фермерського) господарства 3 метою рекреації, освіти чи активного залучення до традиційних форм господарювання [9].

Отже, дотримуючись думки Рутинського М. Й. та Зінька Ю. В., можна стверджувати, що поняття «сільський туризм» за змістом є значно ширшим ніж поняття «агротуризм». А агротуризм є однією 3 найпоширеніших форм сільського туризму [9].

Метою агротуризму $\epsilon$ заняття сільськогосподарськими роботами та аграрною діяльністю, а індивідуальне селянське господарство становить одночасно і нічліжну базу, і головний предмет інтересу туриста. В свою чергу фермерський туризм (farm tourism) $€$ складовою частиною агротуризму, пов'язаною із прийомом туристів безпосередньо у помешканнях фермерського господарства, часто 3 мінімальними вимогами щодо зручностей (особливо щодо умов проживання).

Екологічний туризм (ecotourism) - це пізнавальний i відпочинковий вид туризму, зосереджений на природних (малозмінених людиною) територіях, який передбачає заняття різними формами активної рекреації у природних ландшафтах без заподіяння шкоди навколишньому середовищу. Його синонімами є поняття «зелений туризм» (green tourism) та «природничий туризм» (nature tourism) [9]. В більшості визначень поняття «екотуризм» наголошується, що екотуризм має бути ексклюзивно зарезервованим за природним туризмом i лише подорожі до відносно незайманих i незабруднених природних територій (переважно заповідних) зі специфічними природними атракціями (коралові рифи, озера, карстові печери, зникаючі види тваринного світу) можуть розглядатися як екологічні [10].

Між екотуризмом та сільським туризмом також часто проводять паралелі. Обидва види відповідають критеріям сталого туризму і націлені на збереження 
природного середовища, розвиток традиційної етнокультури, сприяння традиційним формам агрогосподарювання й ремеслам місцевих громад, a у межах природоохоронних територій сільський туризм часто виступає основною організаційною базою розвитку масового екологічного туризму [9].

Сільський туризм і екотуризм відрізняються також основними цілями використання вільного часу. Сільський туризм передбачає проведення вільного часу у формі стаціонарно-радіальних виїздів чи походів, а екотуризм - це вид проведення вільного часу у формі невпинного руху, відкриття дикої природи, маршрутного ознайомлення 3 природними й історичними атракціями території, похідного пізнання традицій і місцевої культури [9].

Закон України «Про туризм» від 15.09.1995 р. також визначає «сільський туризм» - як самостійний вид туризму, а «зелений туризм» - синонімом екологічного [7].

Отже, поняття сільський, агро- та екотуризм мають різне змістовне наповнення та передбачають різну мету діяльності. Але більшість дослідників під сільським туризмом розуміють своєрідний синтез трьох різновидів туризму - екотуризму (зеленого), агротуризму (фермерського) та сільського туризму. Тому часто у вітчизняній науковій літературі зустрічається твердження, що сільський зелений, агротуризм та екотуризм є організаційними формами сільського туризму як такого.

Дубодєлова А. В. узагальнює специфічні риси сільського туризму, що відрізняють його від інших видів, а саме:

- місцем відпочинку $є$ сільська місцевість 3 великим відкритим простором;

- значний вплив сезонних природних факторів;

- відпочинок супроводжується ознайомленням 3 сільською місцевістю, традиціями, обрядами, побутом, історичною спадщиною;

- постачальником туристичних послуг $\epsilon$ сільська громада, в тому числі окреме селянське господарство;

- основна послуга - це проживання в сільській місцевості та участь у діяльності селян;

- послуги туристам надаються особами різних професій, які постійно проживають у сільській місцевості;

- тяжіння до пасивного самодіяльного та соціального туризму;

- глибше розуміння народної культури, формування національно-патріотичної свідомості [5].

Цікавим $є$ визначення сутності сільського туризму Н. Є. Кудли, за яким концептуальна модель організації сільського туризму включає чотири невід'ємні складові - це сільська місцевість, сільська спадщина, сільське життя та сільська діяльність, що поєднуються у сільському туристичному просторі [8].

Отже, розвиток сільського туризму часто пов'язаний із діяльністю сільського господаря розташованого в сільській місцевості домогосподарства, члени якого займаються сільськогосподарською діяльністю з використанням належних їм земельних ділянок. Другим важливим елементом інфраструктури сільського туризму $\epsilon$ сільська садиба - житловий будинок 3 присадибною земельною ділянкою, в якому постійно проживають члени сільського домогосподарства, або інший житловий будинок, що знаходиться за місцем постійного проживання цих осіб та належить за правом власності члену даного господарства [11].

Найчастіше сільський туризм являе собою форму діяльності фермерського господарства або особистого підсобного господарства.

Сільська родина виступає центральною фігурою в організації такого відпочинку. Крім основної діяльності, пов'язаної 3 веденням особистого селянського господарства, вона виконує ще й побічну 3 використанням майна цього господарства для надання відповідних послуг у сфері сільського туризму.

При цьому сільський туризм виконує певні функції, а саме: пізнавальну, оздоровчу, виховну, культурно-освітню, творчу та економічну. Він сприяє оздоровленню відпочиваючих, покращенню їхнього фізичного та душевного стану, розширенню кола спілкування, формуванню та розвитку соціально-культурних зв'язків, обміну досвідом, відродженню промислів і традицій українського народу, бережному використанню природорекреаційних ресурсів, формує дохід громадян, сприяє зростанню зайнятості населення в сільській місцевості та покращенню інфраструктури [8].

Основна послуга сільського туризму - це не просто надання туристам тимчасового проживання в сільській садибі, а формування комплексного обслуговування тих, хто відпочиває.

Висновки. Одним із факторів ефективності наукових досліджень $є$ коректна i адекватна понятійно-термінологічна база. Термінологічний апарат у туризмі ще не достатньо визначений i потребує подальшого осмислення. На сьогодні не існує єдиного визначення сільського туризму як в Україні, так і за кордоном, що часто призводить до визначення його як такого, що охоплює усі форми туризму, які зустрічаються у сільській місцевості, та ототожнення понять сільський зелений, агро- та екотуризм, які мають різне змістовне наповнення та передбачають різну мету діяльності. В першу чергу це пов'язано з диференційованими підходами у різних країнах до сільського туризму як виду діяльності в сільській місцевості. Для максимально ефективного використання його можливостей щодо забезпечення сталого розвитку регіонів в Україні варто затвердити на національному законодавчому рівні понятійний апарат та окреслити сутність та характерні ознаки сільського туризму, залежно від особливостей його історичного розвитку та ресурсного потенціалу території України. 


\section{References:}

1. Byrkovych, B. Sìl's'kij zelenij turizm — prìoritet rozvitku turističnoï galuzì Ukraïni [Rural green tourism as a priority of the Ukrainian tourism industry development]. Strategičnì prioriteti Naukovo-analitičnij sokvartal'nij zbirnik [Strategic Priorities. Scientific and Analytical Quarterly Collection], 2011, No. 1(6), pp. 138-143. (In Ukrainian).

2. Voloshenko, S. Aspekty funkcionirovaniâ sel'skogo turizma [Aspects of the functioning of rural tourism] (Electronic source). Access mode: https://ejournal.vfu.bg/bg/pdfs/Voloshenko.pdf (In Russian).

3. Horishevskyi, P., Vasyliev, V., Zinko, Yu. Sil's'kij zelenij turizm: organizacîa nadannâ poslug gostinnostì [Rural green tourism: organization of providing hospitality services], Ivano-Frankivsk: misto NV, 2003,148 p. (In Ukrainian).

4. Дарчук В. Г. Формування стратегічних основ розвитку сільського (зеленого) туризму в Україні : автореф. дис. ... канд. екон. наук : спец. 08.00.03 / В. Г. Дарчук. - Донецьк, 2014. - 21 с. (In Ukrainian).

5. Dubodielova, A., Malkush, Kh. Osoblivostì ta tendenciï rozvitku sìl's'kogo turizmu v Ukraïnì [Specificity and trends of rural tourism development in Ukraine]. Scientific Bulletin of Ukrainain National Forest University, 2013, Vol. 23 (2), pp. 118-123. (In Ukrainian).

6. Експерт Світової туристичної організації назвав найперспективніші види туризму для України (інтерв’ю) [Електронний ресурс]. - 2018. - Режим доступу до ресурсу: https://dyvys.info/2018/11/03/ ekspert-svitovoyi-turystychnoyi-organizatsiyi-nazvav-najperspektyvnishi-vydy-turyzmu-dlya-ukrayiny-intervyu/?fbclid=IwAR3X1zXYjSLSo_kEDQ16O_-q54wAZ9WRCbWMs0GzvxTDCpSacFYjQqOniqQ.

7. Ivanova V. «Sill's'kij turizm» âk kategorìa nauki admìnìstrativnogo prava ta zakonodavstva ["Rural tourism" as a category of administrative law and legislation]. Pravo i suspil'stvo [Law and Society], 2010, No. 3, pp. 119-125. (In Ukrainian).

8. Kudla, N. Sill's'kij turizm: osnovi pìdpriêmnictva ta gostinnostì: navčal'nij posibnik [Rural tourism: the basics of entrepreneurship and hospitality: teaching manual], Kyiv: Tsentr Uchbovoyi Literatury, 2015, 152 p. (In Ukrainian).

9. Rutynskyi, M., Zinko, Yu. Sil's'kij turizm: navčal'nij posibnik [Rural tourism: teaching manual], Kyiv: Znannia, 2006, 271 p. (In Ukrainian).

10. Смаль В., Смаль І. Туризм і сталий розвиток / В. Смаль, І. Смаль // Вісник Львівського ун-ту. Серія географічна. - 2005. - Вип. 32. - С. 163-173

11. Trillenberh, H. Sil's'kij turizm - važlivij važil' ekonomičnogo pìdjomu depresivnih teritorìj[Rural tourism is an important lever for the economic recovery of depressed areas]. Visnik TNEU [Scientific Bulletin of Ternopil National Economic University], 2012, No. 2, pp. 159-167. (In Ukrainian).

12. Faryon, O. Sil's'kij zelenij turizm: ponâttâ, funkciï j tendenciï rozvitku v Ukraïnì ta svìtì [Rural green tourism: the concept, functions and trends of development in Ukraine and in the world]. Aktual'ni problemi rozvitku ekonomiki regionu [The Actual Problems of Regional Economy Development], 2013, Vol. 9 (2), pp. 151-156. (In Ukrainian).

\section{Список використаних джерел:}

1. Биркович В. І. Сільський зелений туризм - пріоритет розвитку туристичної галузі України / В. I. Биркович / Стратегічні пріоритети. Науково-аналітичний щоквартальний збірник. — 2011. — №1(6). — C. $138-143$

2. Волошенко С. С. Аспекты функционирования сельского туризма [Електронний ресурс] / С. С. Волошенко // - Режим доступу до ресурсу: https://ejournal.vfu.bg/bg/pdfs/Voloshenko.pdf

3. Горішевський П. Сільський зелений туризм: організація надання послуг гостинності / Горішевський П., Васильєв В., Зінько Ю. - Івано-Франківськ: місто НВ, 2003. - 148 с.

4. Дарчук В. Г. Формування стратегічних основ розвитку сільського (зеленого) туризму в Україні : автореф. дис. ... канд. екон. наук : спец. 08.00.03 / В. Г. Дарчук. - Донецьк, 2014. - 21 с.

5. Дубодєлова А. В. Особливості та тенденції розвитку сільського туризму в Україні / Дубодєлова А. В., Малкуш Х. Ю. // Наук. вісн. НЛТУ України. - 2013. - Вип. 23.2. - С. 118-123

6. Експерт Світової туристичної організації назвав найперспективніші види туризму для України (інтерв’ю) [Електронний ресурс]. - 2018. - Режим доступу до ресурсу: https://dyvys.info/2018/11/03/ ekspert-svitovoyi-turystychnoyi-organizatsiyi-nazvav-najperspektyvnishi-vydy-turyzmu-dlya-ukrayiny-intervyu/?fbclid=IwAR3X1zXYjSLSo_kEDQ16O_-q54wAZ9WRCbWMs0GzvxTDCpSacFYjQqOniqQ.

7. Іванова В. Г. «Сільський туризм» як категорія науки адміністративного права та законодавства / В. Г. Іванова // Право і суспільство. - 2010. - № 3. - С. 119-125

8. Кудла Н. Є. Сільський туризм: основи підприємництва та гостинності: навч. посіб. / Н. Є. Кудла. - К.: “Центр учбової літератури”, 2015. - 152 с.

9. Рутинський М. Й. Сільський туризм: навч. посіб. / М. Й. Рутинський, Ю. В. Зінько. - К.: Знання, 2006. $-271 \mathrm{c}$.

10. Смаль В., Смаль І. Туризм і сталий розвиток / В. Смаль, І. Смаль // Вісник Львівського ун-ту. Серія географічна. - 2005. - Вип. 32. - С. 163-173

11. Трілленберг Г. Сільський туризм - важливий важіль економічного підйому депресивних територій / Г. Трілленберг // Вісник ТНЕУ. - 2012. - № 2. - С. 159-167.

12. Фарйон О.О. Сільський зелений туризм: поняття, функції й тенденції розвитку в Україні та світі / О. О. Фарйон // Актуальні проблеми розвитку економіки регіону: науковий збірник / [за ред. I. Г. Ткачук]. Івано-Франківськ: Вид-во Прикарпатського національного університету імені Василя Стефаника, 2013. Вип. 9. - Т. 2. - С. 151-156. 